\title{
Structuring of Indo-Pacific fish assemblages along the mangrove-seagrass continuum
}

\author{
Richard K. F. Unsworth ${ }^{1,5, *}$, Samantha L. Garrard ${ }^{2}$, Pelayo Salinas De León ${ }^{3}$, \\ Leanne C. Cullen ${ }^{4}$, David J. Smith ${ }^{5}$, Katherine A. Slomann ${ }^{2}$, James J. Bell ${ }^{3}$ \\ ${ }^{1}$ Northern Fisheries Centre, Department of Primary Industries and Fisheries, PO Box 5396, Cairns, Queensland 4870, Australia \\ ${ }^{2}$ School of Biological Sciences, University of Plymouth, Drake Circus, Plymouth PL4 8AA, UK \\ ${ }^{3}$ Centre for Marine Environmental and Economic Research, School of Biological Sciences, Victoria University of Wellington, \\ PO Box 600, Wellington, New Zealand \\ ${ }^{4}$ CSIRO Sustainable Ecosystems, James Cook University, PO Box 12139, Earlville BC, Cairns, Queensland 4870, Australia \\ ${ }^{5}$ Coral Reef Research Unit, Department of Biological Sciences, University of Essex, Wivenhoe Park, Colchester CO4 3SQ, UK
}

\begin{abstract}
Indo-Pacific mangrove swamps and seagrass beds are commonly located in close proximity to each other, often creating complex ecosystems linked by biological and physical processes. Although they are thought to provide important nursery habitats for fish, only limited information exists about their usage by fish outside of estuaries. The present study investigated fish assemblages in non-estuarine intertidal habitats where mangroves and seagrass overlap (the mangrove-seagrass continuum). Three habitats (mangrove, mangrove edge, seagrass) were sampled at 4 sites of the Wakatobi Marine National Park, Indonesia, using underwater visual census. Ninety-one species of fish were observed at a mean density of $130.1 \pm 37.2$ ind. $1000 \mathrm{~m}^{-2}$. Predatory fish (fish that feed on invertebrates and/or fish) were the most dominant feeding groups in the mangroves, whilst omnivores dominated on the mangrove edge and in the seagrass. Although the habitats along the mangrove-seagrass continuum were observed to be important for many fish, only 22 of the 942 coral reef species known within the area utilised mangroves as nursery habitat and only 15 utilised seagrass. Despite finding evidence that nursery grounds in mangroves and seagrass may not directly support high coral reef fish diversity, many of the coral reef nursery species found in this study are likely to be key herbivores or apex predators as adult fish on local coral reefs, and thus highly important to local fisheries. Although mangroves are not permanently inundated by the tide, this study highlights their importance as fish habitats, which at high tide support a greater abundance of fish than seagrass beds. In the light of the high rate of destruction of these habitats, their role in supporting fish assemblages requires consideration in marine resource management programs.
\end{abstract}

KEY WORDS: Mangrove-seagrass continuum · Seascapes · Connectivity · Fish assemblages · Trophic structuring $\cdot$ Juvenile habitats $\cdot$ Indonesia

\section{INTRODUCTION}

Mangroves often occur in close association with coral reefs and seagrass beds, forming a complex ecosystem linked by biological and physical processes (Parrish 1989, Dorenbosch et al. 2005, Sheaves 2005, Unsworth et al. 2008). One third of the world's mangrove forests have been lost in the past $50 \mathrm{yr}$, mostly due to human activities (Alongi 2002), and are declining at rates possibly faster than coral reefs and tropical rainforests (Duke et al. 2007). Similarly, high rates of seagrass loss have also been observed throughout the world (Orth et al. 2006). Understanding the degree of utilisation of these habitats by fish communities is important in aiding the development and implementation of effective resource management programs. 
The role of non-estuarine mangroves as a nursery ground for coral reef fish remains highly controversial (Nagelkerken 2007, Nagelkerken et al. 2008). Although, within regions such as tropical Australia, estuarine mangroves have commonly been found to harbour high densities of juvenile fish (Robertson \& Duke 1987 , Blaber et al. 1989, Blaber et al. 1995) and make a large contribution to coastal fisheries productivity, these are not always coral reef fish. Within the Indo-Pacific, mangroves have often been considered to play a very limited role as nursery habitats for coral reef fish (Parrish 1989, Williams 1991, Laroche et al. 1997, Nagelkerken et al. 2008, Unsworth et al. 2008). The management of coral reefs throughout the Indo-Pacific is of critical importance due to their continuing degradation (Wilkinson 2008). Knowledge of nursery habitats associated with these coral reefs is important in making informed management decisions.

Several reasons have been proposed for the use of mangroves and seagrass beds by fish as juvenile habitats, including: (1) their function as a refuge from predation (Parrish 1989, Robertson \& Blaber 1992), (2) the abundance of feeding resources (Hemminga \& Duarte 2000, Baldo \& Drake 2002), (3) their ability to intercept planktonic fish larvae (Parrish 1989), (4) the reduced predator density (Parrish 1989), and (5) the turbidity decreasing the foraging efficiency of predators (Robertson \& Blaber 1992). These roles have largely been investigated in studies of highly turbid estuarine mangroves with various ecological processes and in clearer water mangroves that do not have interactions with nutrient-rich freshwater flows.

Seagrass and mangrove habitats are best known for their 'nursery' function. However, many species of fish spend their whole lifecycle in these shallow water habitats (Sheaves 2005), whilst many adult fish routinely undertake tidal and diel migrations between these and adjacent habitats (Nagelkerken et al. 2000, Dorenbosch et al. 2004, Nagelkerken \& van der Velde 2004, Unsworth et al. 2007a,b). In the Indo-Pacific, tidal ranges are often high and mangroves can commonly be alternately flooded or exposed during the tidal cycle (Sheaves 2005). Apart from some species from the family Gobiidae, which have specialised air-breathing capabilities (Park et al. 2006), fish that utilise mangroves during high tide must migrate to adjacent lower habitats when the tide is low (Vance et al. 1996). These migrations away from mangroves at low tide are likely to be towards neighbouring deeper habitats such as seagrass beds (Vance et al. 1996, Marguillier et al. 1997, Lugendo et al. 2006), suggesting that the biological connectivity between these 2 habitats is prominent.

As well as possibly supporting the productivity of coral reef fish communities, Indo-Pacific non-estuarine mangroves may also harbour high densities of addi- tional fish species. Many species of fish are thought to be common to both seagrass and mangrove habitats (Baelde 1990, Yáñez-Arancibia et al. 1993, Unsworth et al 2008), whilst seagrass beds close to mangroves show greater fish diversity than seagrass beds alone (Nagelkerken et al. 2001, Lugendo et al. 2005, Unsworth et al. 2008). This enhanced diversity appears to show a dependence on a combination of mangroves and seagrass beds, showing that an interaction between the two habitats confers an advantage to fish, enhancing species richness (Unsworth et al. 2008).

The present study investigated fish assemblages of the mangrove-seagrass continuum; mangrove, edge of mangroves (the mangrove-seagrass interface), and seagrass. The aims of this investigation were to (1) determine the habitat usage of the seagrass-mangrove continuum by fish species, (2) examine how fish assemblages vary with respect to trophic structure, and (3) establish whether the seagrass-mangrove continuum operates as habitat for juvenile coral reef fish.

\section{MATERIALS AND METHODS}

Study Design. The present study was conducted during July and August 2006 in the Kaledupan sub-region of the Wakatobi Marine National Park (WMNP), a group of islands off SE Sulawesi, Indonesia, known for their high diversity of marine life (Halford 2003). This coastal zone is characterized by high coverage of seagrass, mangroves and coral reefs. Seagrass beds consisted of mixed seagrasses dominated by Thallassia hemprichii and Enhalus acoroides (Unsworth et al. 2007c). Mean percentage seagrass coverage ranged from 48.8 to $79.5 \%$ (Unsworth et al. 2008). Mangrove forests were dominated by Rhizophora spp., although lower densities of Avennicia spp. and Brugiera spp. were found at both Darawa sites. Semi-diurnal tides in this area show an average tidal range of approximately $1.5 \mathrm{~m}$ (Unsworth et al 2007a), with intertidal mangrove forests exposed at low tide.

Four sites were chosen (Fig. 1); Darawa Village $\left(05^{\circ} 55^{\prime} 54.2^{\prime \prime} \mathrm{S}, 123^{\circ} 86^{\prime} 40.4^{\prime \prime} \mathrm{E}\right)$, Darawa Mangroves $\left(05^{\circ} 54^{\prime} 80.6^{\prime \prime} \mathrm{S}, \quad 123^{\circ} 87^{\prime} 12.1^{\prime \prime} \mathrm{E}\right), \quad$ Languira $\left(05^{\circ} 47^{\prime}\right.$ $\left.57.9^{\prime \prime} \mathrm{S}, 123^{\circ} 71^{\prime} 91.0^{\prime \prime} \mathrm{E}\right)$ and Sombano $\left(05^{\circ} 48^{\prime} 02.1^{\prime \prime} \mathrm{S}\right.$, $\left.123^{\circ} 69^{\prime} 86.4^{\prime \prime} \mathrm{E}\right)$. The 4 sites are all adjacent to small offshore islands and are exclusively marine, with no riverine influence. They border onto seagrass meadows and lie in close proximity to coral reefs. They are at a distance of least $100 \mathrm{~m}$ from the land and located well away from the immediate vicinity of a large population centre; consequently, they were not considered to be affected by anthropogenic factors.

The only freshwater input is from diffuse terrestrial run-off during the wet season. Environmental char- 

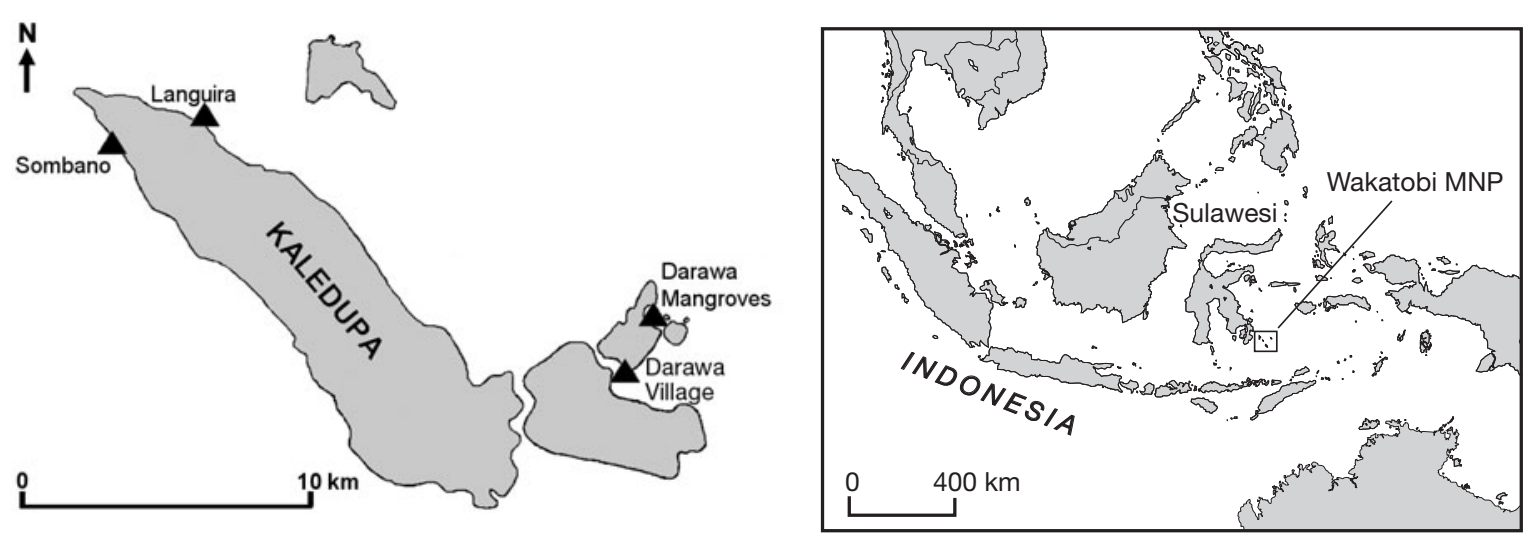

Fig. 1. Location of the 4 study sites within the Kaledupa sub-region of the Wakatobi Marine National Park, SE Sulawesi, Indonesia

acteristics of the individual sites are summarized in Table 1. The mangrove sites are located near reef environments and adjacent to seagrass habitats; seagrass habitats are within a deeper intertidal range and not as abundantly exposed as mangroves. Further descriptions of these sites can be found in Unsworth et al. (2008). To study the abundance and size distribution of different fish species along the mangrove-seagrass continuum, 3 habitats were distinguished: mangrove (inside the mangroves; at least $50 \mathrm{~m}$ into the mangrove and away from the outer edge, and not within large open mangrove channels), mangrove edge (the very outer seaward facing edge of the mangrove), and seagrass (50 $\mathrm{m}$ away from the mangrove outer seaward edge in continuous seagrass cover).

At each of the 4 sites, 6 repeat visual transects were conducted within each of the 3 habitats yielding a total of 72 transects. In order to conduct the visual transects, observers were trained at estimating fish lengths underwater by repeatedly estimating the lengths of objects of known length underwater (see English et al 1997). Habitats were sampled using an underwater visual census (UVC) method with snorkelling equipment and $50 \mathrm{~m}$ belt transects. Transects in the seagrass were laid $50 \mathrm{~m}$ into the seagrass parallel to the mangroves, and transects on the edge of the mangroves were laid $3 \mathrm{~m}$ from the edge and parallel to the mangroves. In these

Table 1. Environmental and location characteristics (mean $\pm \mathrm{SE}$ ) of the 4 sites located in the Kaledupa sub-region of Wakatobi Marine National Park, Indonesia. All measurements were taken along the seaward edge of the mangrove

\begin{tabular}{|lcccc|}
\hline Site & $\begin{array}{c}\text { Visibility } \\
(\mathrm{m})\end{array}$ & $\begin{array}{c}\text { Temp } \\
\left({ }^{\circ} \mathrm{C}\right)\end{array}$ & $\begin{array}{c}\text { Salinity } \\
(\% \circ)\end{array}$ & $\begin{array}{c}\text { Distance } \\
\text { to coral } \\
\text { reef }(\mathrm{km})\end{array}$ \\
\hline Langeira Beach & $5.3 \pm 0.2$ & $28.4 \pm 0.0$ & $34 \pm 2$ & 0.6 \\
Sombano Beach & $4.7 \pm 1.0$ & $30.4 \pm 0.0$ & $33 \pm 3$ & 0.9 \\
Darawa Mangroves & $4.5 \pm 0.1$ & $28.3 \pm 0.0$ & $34 \pm 2$ & 0.9 \\
Darawa Village & $6.0 \pm 0.1$ & $28.3 \pm 0.0$ & $33 \pm 2$ & 1.2 \\
\hline
\end{tabular}

2 habitats, fish were counted in an area $2.5 \mathrm{~m}$ either side of the transect tape, giving a total sampling area of $250 \mathrm{~m}^{2}$. Due to the shade and decreased visibility within the mangroves, fish were counted within $1 \mathrm{~m}$ either side of the transect, giving a total area of $100 \mathrm{~m}^{2}$. In order to compare data between habitats and with other studies, all data is presented as ind. $1000 \mathrm{~m}^{-2}$. Prior to laying transects, a number of preliminary site visits were conducted in order to determine suitable places to conduct transects, i.e. those places where an observer could move between mangrove trees and prop roots at high tide. Conducting these mangrove belt transects was extremely challenging due to the dense forest. For example, observers commonly pushed their way through tight branches in order to continue transects. Unfortunately, some transects could not be fully completed and were instead broken and restarted at the nearest possible location. Although not a commonly used methodology, mangrove UVC studies have previously been conducted in Rhizophora mangrove of both the Indo-Pacific and the Caribbean (Nagelkerken \& van der Velde 2002, Dorenbosch et al. 2005, 2007, Aguilar-Perera and Appeldoorn 2007). Difficulties associated with the use of UVC within mangroves, such as observer bias and fish behaviour, are extensively discussed by Nagelkerken \& van der Velde (2002). All transects were conducted during daylight between 07:00 $\mathrm{h}$ and 17:00 $\mathrm{h}$ at periods of high tide, when the mangroves and seagrass beds were fully flooded. On a couple of occasions, conditions between mangroves were too turbid and dark to conduct observations, particularly in locations where sand had a dark colour; therefore these transects were conducted at the next available occasion. As with any visual observation method in any vegetated environment, it is likely that small and cryptic species were underestimated (Edgar et al. 2004). Many mangroves in and around estuarine environments are commonly highly turbid, shallow, and inappropriate for UVC of fish assemblages. However, the present study was based 
within non-estuarine mangroves surrounding small offshore islands. At high tide, mangroves in the WMNP become inundated by clear oceanic waters that allow for high visibility and water depths commonly exceeding $1.5 \mathrm{~m}$. Despite the clear water, the observation of fish species within shaded prop roots remained difficult and required a number of training sessions prior to observations being undertaken (Nagelkerken \& van der Velde 2002).

Data analysis. All summary statistics are presented as means $\pm \mathrm{SE}$, with the exception of size distribution across habitats, which was presented as median values \pm interquartiles due to data following a Poisson distribution. Fish species were classified as juveniles when under $1 / 3$ their maximum length unless their maximum length exceeded $90 \mathrm{~cm}$, in which case they were classified as juveniles when under $30 \mathrm{~cm}$ (after Nagelkerken $\&$ van der Velde 2002). Maximum lengths were based on data in Fishbase (Froese \& Pauly 2008; www.fishbase.org). Each fish species was assigned a feeding category (fish and invertebrate feeder, invertivore, herbivore, omnivore or planktivore) after Unsworth et al. (2007a). Multiple sources were used in order to ensure placement of species in the correct trophic feeding category (Hutomo \& Peristiwady 1996, Khalaf \& Kochzius 2002, Nakamura et al. 2003, Froese \& Pauly 2008).

All univariate analyses were performed using MINITAB 15 software. Data was tested for model conformity to meet assumptions for analysis of variance (ANOVA) using Levene's test and, where necessary, the data was $\log (x+1)$ transformed to meet the requirements. Comparisons of overall fish abundance, species richness, abundance of each trophic category and juvenile and adult abundances between sites and habitats along the mangrove-seagrass continuum were analyzed using 2-way ANOVAs. Post-hoc Tukey's tests were conducted to determine individual inter-site differences. Multivariate analysis of community assemblage data was conducted using Primer v6 software (Plymouth Marine Laboratory). The Bray-Curtis similarity index was applied to square-root transformed data (to reduce the influence of abundant and rare species), resulting in a triangular similarity matrix. A non-metric multidimen- sional scaling (nMDS) ordination of similarity matrices was used to test for significant differences in species assemblages between habitats at each site. Confirmation of differences in assemblage structure was conducted using analyses of similarities (ANOSIM). A similarity percentage (SIMPER) analysis was used to determine which species were contributing to the differences observed by the ANOSIM (Clarke \& Warwick 1994). It was not possible to use parametric tests to analyze size distribution between habitats, as data followed a Poisson distribution and did not conform to the assumptions of ANOVA. Comparisons of length-frequency distributions between habitats using two-sample KolmogorovSmirnov tests showed that distributions were significantly different between habitats. A Kruskall-Wallis test was used to perform the non-parametric equivalent of an ANOVA, looking at the difference in fish lengths between habitats along the mangrove-seagrass continuum. Further individual non-parametric Mann-Whitney $U$-tests were conducted to determine differences in length between each individual habitat.

\section{RESULTS}

\section{Fish assemblage composition}

A total of 91 species from 32 families were observed during the study period (Appendix 1, Table A1). The average fish abundance was $130.1 \pm 37.2$ ind. $1000 \mathrm{~m}^{-2}$ and the average fish species richness was $6.3 \pm 0.8$ species. Numerically, the most dominant families were: Atherinidae (55.5\%), Apogonidae (19.2\%), Siganidae $(5.9 \%)$ and Labridae $(3.4 \%)$. In terms of numbers of species per family, the most dominant were: Labridae (11 species, 12.1\%), Pomacentridae (10 species, $11.0 \%$ ), Apogonidae (6 species, $7.0 \%$ ) and Nemipteridae (6 species, $7.0 \%$ ).

Total fish abundance differed significantly along the seagrass-mangrove continuum (Table 2). Post-hoc Tukey's tests showed that fish abundance was significantly greater in the mangroves than on the mangrove edge or in the seagrass (Fig. 2a). No difference was

Table 2. Two-way GLM ANOVA results for adult, juvenile and total fish abundances in 3 habitat types (mangrove, mangrove edge and seagrass) across 4 sites in the Kaledupa subregion of the Wakatobi Marine National Park, Indonesia. Fish were sampled using underwater visual census. Seq SS: sequential sum of squares

\begin{tabular}{|c|c|c|c|c|c|c|c|c|c|c|}
\hline \multirow[b]{2}{*}{ Source } & \multirow[b]{2}{*}{ df } & \multicolumn{3}{|c|}{ Juveniles - } & \multicolumn{3}{|c|}{$\Delta$ dults } & \multirow[b]{2}{*}{ Seq SS } & \multirow{2}{*}{$\begin{array}{c}\text { All Fish } \\
\qquad F\end{array}$} & \multirow[b]{2}{*}{$\mathrm{p}$} \\
\hline & & Seq SS & F & $\mathrm{p}$ & Seq SS & $F$ & $\mathrm{p}$ & & & \\
\hline Site & 3 & 1.0 & 0.9 & $>0.1$ & 1.6 & 2.0 & 0.119 & 1.2 & 2.5 & $>0.5$ \\
\hline Habitat & 2 & 10.4 & 13.7 & $<0.0001$ & 20.2 & 39.0 & $<0.0001$ & 27.2 & 82.2 & $<0.0001$ \\
\hline Interaction & 6 & 0.5 & 0.2 & $>0.1$ & 2.5 & 1.6 & 0.17 & 0.7 & 0.7 & $>0.1$ \\
\hline Error & 60 & 22.8 & & & 15.6 & & & 9.9 & & \\
\hline Total & 71 & 34.8 & & & 39.9 & & & 39.1 & & \\
\hline
\end{tabular}



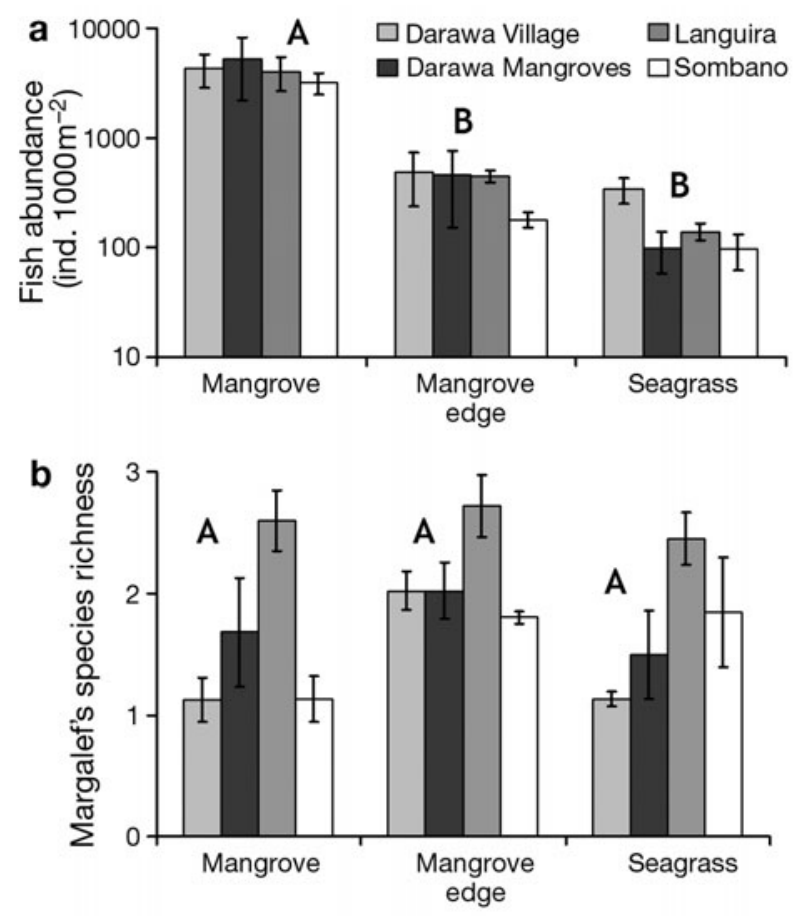

Fig. 2. (a) Abundance and (b) richness of fish assemblages (mean $\pm \mathrm{SE}$ ) within the mangrove, mangrove edge and seagrass habitat sites sampled. Different letters indicate significant differences between habitats as determined by post-hoc Tukey comparisons $(\mathrm{p}<0.01)$

found in fish abundances between study sites. Species richness showed significant variability between sites $\left(F_{71}=11.17, \mathrm{p}<0.001\right)$, but not between habitats along the mangrove-seagrass continuum (Fig. 2b). Post-hoc Tukey comparisons showed that the Languira site showed significantly greater species richness than the other study sites $(p<0.01)$. Richness did not vary between the other study sites.

Fish assemblages varied significantly (Global $\mathrm{R}=$ 0.619, $\mathrm{p}<0.01$ ) throughout the mangrove-seagrass continuum (Fig. 3). No significant difference in assem-

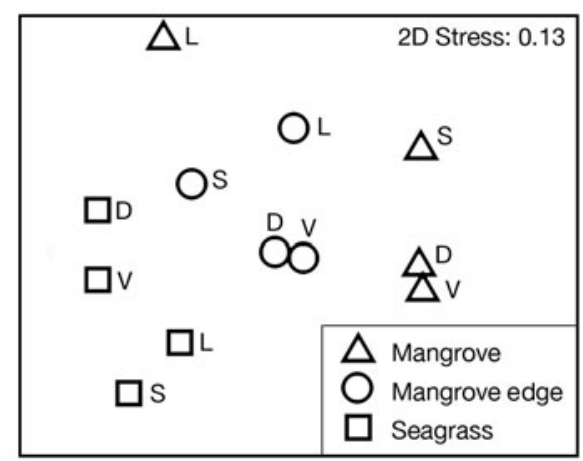

Fig. 3. nMDS plot of fish assemblages in different habitats within 4 different sites of the Kaledupa sub-region of the Wakatobi Marine National Park. Fish assemblages were sampled using underwater visual census. V: Darawa Village, D:

Darawa Mangroves, L: Languira; S: Sombano

blage composition was found between sites. Atherinomorus lacunosus and Lutjanus ehrenbergii were the most representative species of the mangrove habitat, Scolopsis trilineatus and Choerodon anchorago were most representative of the mangrove edge, and Lethrinus harak and Siganus canaliculatus were most representative of the seagrass habitat (Table 3).

\section{Trophic structuring}

There was a significant difference in the abundance of omnivores between sites $\left(F_{3,71}=9.19, \mathrm{p}<0.001\right)$, but no difference was found in their abundance along the mangrove-seagrass continuum (Fig. 4). Fish and invertebrate feeders were found in significantly greater numbers in the mangroves than in the seagrass $\left(F_{3,71}=\right.$ $4.38, \mathrm{p}=0.017$ ), although there was between-site variability within this trophic category. Invertivores did not show between-site variability and were consistently found in higher abundances in the mangroves than in the seagrass $\left(F_{3,71}=4.32, \mathrm{p}=0.018\right)$. The herbivore

Table 3. SIMPER analysis of individual habitat similarity to determine those fish groups, in terms of abundance, that comprise $>4 \%$ similarity within all 3 habitats (mangrove, mangrove edge and seagrass). SIMPER was calculated using fish abundance data recorded using underwater visual census at 4 sites (Darawa, Darawa Village, Languira and Sombano) in the Wakatobi Marine National Park. \% SC: percent similarity contribution

\begin{tabular}{|c|c|c|c|c|c|}
\hline \multicolumn{2}{|c|}{ Mangrove } & \multicolumn{2}{|c|}{ - Mangrove edge } & \multicolumn{2}{|l|}{$\longrightarrow$ Seagrass } \\
\hline Fish species & $\% \mathrm{SC}$ & Fish species & $\% \mathrm{SC}$ & Fish species & $\% \mathrm{SC}$ \\
\hline Atherinomorus lacunosus & 47.8 & Scolopsis trilineatus & 22.2 & Lethrinus harak & 30.0 \\
\hline Lutjanus ehrenbergii & 9.1 & Choerodon anchorago & 17.7 & Siganus canaliculatus & 27.7 \\
\hline Lethrinus harak & 6.4 & Gerres oyena & 10.8 & Gerres oyena & 9.6 \\
\hline Sphaeramia orbicularis & 5.0 & Lethrinus harak & 9.8 & Scolopsis trilineatus & 7.2 \\
\hline Scolopsis ghanam & 4.9 & Acanthurus grammoptilus & 7.1 & Siganus fuscescens & 6.5 \\
\hline \multirow[t]{4}{*}{ Scolopsis trilineatus } & 4.8 & Siganus canaliculatus & 6.9 & Halichoeres argus & 4.8 \\
\hline & & Dischistodus fasciatus & 5.7 & & \\
\hline & & Goby sp. & 5.1 & & \\
\hline & & Lutjanus ehrenbergii & 4.2 & & \\
\hline
\end{tabular}




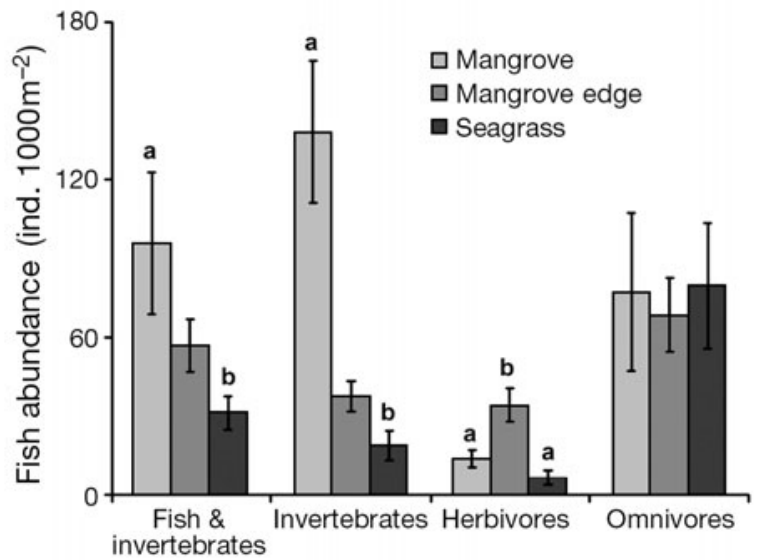

Fig. 4. Abundances of fish in different feeding categories in each of the 3 habitats: (mangrove, mangrove edge, seagrass) within the Kaledupa sub-region of the Wakatobi Marine National Park. Results are means \pm SE for each habitat across the 4 study sites. Different letters indicate significant $(p<0.05)$ differences between habitats

feeding category contained the fewest individuals (Fig. 4). These herbivores were found in highest abundances along the mangrove edge, although variability was significant between sites as well as between habitats. Atherinomorus lacunosus and Sphaeramia orbicularis had to be removed from the analysis; due to their shoaling nature, their very high abundances skewed any comparative analysis. A. lacunosus were the only planktivorous fish which occurred at these sites throughout this study period. S. orbicularis are fish and invertebrate feeders. Both species were found almost exclusively within the inner mangrove habitat.

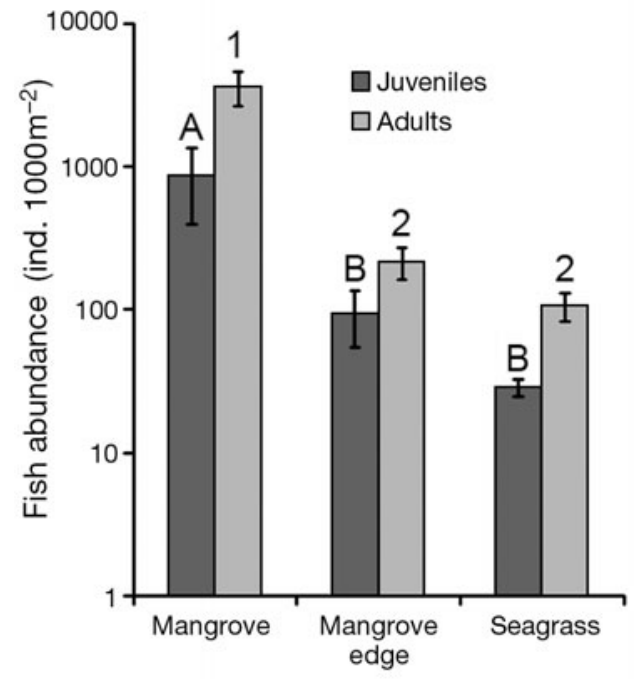

Fig. 5. Abundance of adults and juveniles (mean $\pm \mathrm{SE}$ ) in 3 habitats (mangrove, mangrove edge, seagrass) within the Kaledupa sub-region of the Wakatobi Marine National Park. Comparisons of juvenile and adult abundances were made using 2 -way GLM ANOVA. Significant $(p<0.05)$ Tukeys pairwise differences between juvenile fish abundance in each habitat are represented by letters; adults by numbers

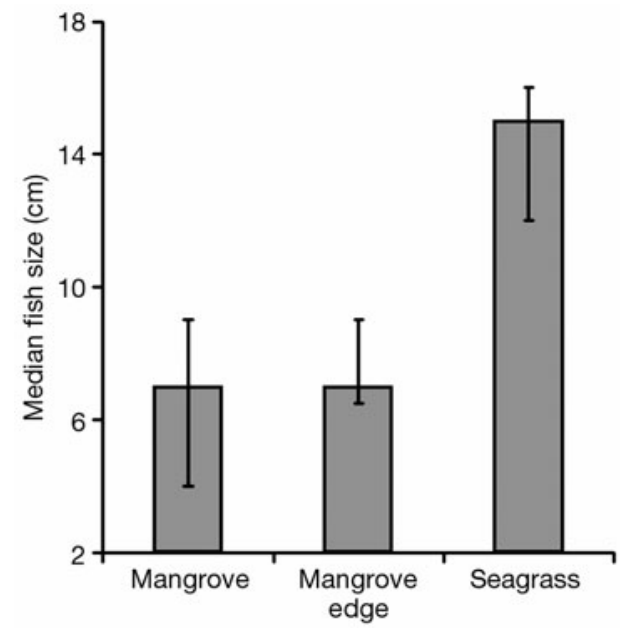

Fig. 6. Median sizes of fish ( \pm interquartile ranges) found in mangrove, mangrove edge and seagrass habitats within the Kaledupa sub-region of the Wakatobi Marine National Park.

Fish sizes were surveyed using underwater visual census

\section{Juvenile and length distributions across habitats}

There were no significant differences in juvenile or adult abundances between study sites; however, the abundance of both juveniles and adults was significantly higher within mangroves than in the other 2 habitats (Fig. 5, Table 2). Fish size differed significantly overall between habitats $\left(\chi^{2}=1646.520, \mathrm{p}<\right.$ 0.001) (Mann-Whitney $U$-test); however, median fish length (Fig. 6) was greater in seagrass beds than in any of the mangrove habitats where little difference between habitats was observed.

Of the 91 species recorded within seagrass and mangrove habitats, 50 have previously been recorded on local coral reefs (Halford 2003). Mangrove habitats were found to contain juveniles of 39 species, at least 22 of which have previously been recorded as adult fish on local coral reefs (Halford 2003). Of the 26 species found as juveniles within seagrass habitat, 15 have previously been recorded on local coral reefs (Halford 2003).

\section{DISCUSSION}

The results of the present study show that non-estuarine mangroves and seagrass beds are important habitats for diverse fish assemblages within the IndoPacific and that they also have a nursery function. However, this function may be limited for coral reef species. Many of the abundant species (e.g. Lethrinus harak) were found to inhabit all 3 habitats (mangrove, mangrove edge, seagrass), indicating that individuals may move between them. An important finding of the present study was that distinct assemblages were present within all 3 habitats irrespective of site, indicating 
that many species may inhabit specific zones within this mangrove-seagrass continuum.

The species assemblages within this non-estuarine mangrove-seagrass continuum consisted of many species found in comparable earlier studies in this region (Thollot 1992, Laroche et al. 1997, Dorenbosch et al. 2005). Mangrove habitats were numerically dominated by species of the family Atherinidae, which is consistent with the findings of studies throughout northern Australian estuarine mangroves (Robertson \& Duke 1990, Laegdsgaard \& Johnson 2001). The high density of Atherinomorous lacunosus likely indicates an abundant source of plankton within these mangrove forests. Other families of fish commonly found within mangroves in the present study (e.g. Lethrinidae, Lutjanidae, Gerridae) contain many species found in mangroves of other studies (Thollot 1992, Laroche et al. 1997).

Although there were many similarities with other studies, the fish assemblages found within mangroves in the present study were strikingly different from other Indo-Pacific mangrove studies due to a high density of the family Apogonidae. Abundant species of Apogonidae, such as Sphaeramia orbicularis and Apogon ceramensis, are predators of small fish and crustaceans. The specific reasons for these differences are not clear; however, the abundance of particular crustaceans or greater visibility may make hunting by species of Apogonidae within these non-estuarine mangroves more successful than in other estuarine mangroves that have been studied throughout this region (Quinn \& Kojis 1985, Sasekumar et al. 1992, Thollot 1992).

Many studies have demonstrated that the presence of mangroves increases species density in adjacent seagrass beds (Nagelkerken et al. 2001, Lugendo et al. 2005, Jelbart et al. 2007, Unsworth et al. 2008), suggesting that the presence of mangroves confers some form of advantage to fish. Of the 91 species found within seagrass and mangroves in the present study, 50 have previously been recorded in reef habitats. It is likely that, in the present study, the flooded mangroves are only a temporary fish habitat, and refuge is sought in adjacent habitats such as seagrass and reef when the tide goes out. This illustrates that many species utilise both mangrove and seagrass habitats, and that some coral reef and seagrass fish will utilise the shelter and resources of a nearby mangrove habitat (Nagelkerken et al. 2008).

Fish that fed either wholly or partly on a diet of invertebrates contributed to the majority of species present in mangroves. This is consistent with earlier studies, which found little evidence for fish species utilising mangrove productivity directly. However, species of Mugilidae, which were frequently observed during the present study, can consume significant amounts of mangrove detritus (Sasekumar et al. 1992), and both Siganidae and
Pomacentridae may utilise mangrove flora as food (Marguillier et al 1997). The diet of carnivorous fish varies throughout their life cycle, with an increase in prey size with increasing length (Baldo \& Drake 2002), which is likely to reduce competition. Juveniles of large piscivorous fish such as Sphyraenidae and Carangidae were observed foraging around the mangrove/seagrass interface, probably looking for and chasing schools of fish such as hardyheads (R. K. F. Unsworth pers. obs.). Such predatory fish may be important in structuring fish assemblages within these mangroves. Species of Sphyraenidae and Carangidae are more likely to use physical structure to increase predation efficiency, rather than as protection (Verweij et al. 2006).

The distinct assemblages present within each habitat suggests that, although the shelter of these mangroves is likely to confer advantages for some species of fish, this is not true for all. Refuge from predation is likely to be of greater importance to smaller fish within these habitats. The median size of fish in the mangroves and on the mangrove edge was much smaller than in the seagrass. This is likely due to the habitat complexity (Nagelkerken \& van der Velde 2002) and shade (Verweij et al. 2006) offered by the mangroves, which are likely to reduce predation pressure and influence smaller fish to preferentially utilise the mangrove habitat. Larger fish, which are less at risk from predation, may prefer to remain in the seagrass beds where food is abundant (Ogden \& Zeimann 1977).

The abundance of juveniles observed during this study was low in comparison to the abundance of adults, which is in contrast to recent studies in other non-estuarine mangroves (Aguilar-Perera \& Appeldoorn 2007). Lugendo et al. (2005) suggested that seagrass beds within the Indo-Pacific may function as corridors between mangroves and coral reefs for reef fish that undertake ontogenic migrations, from shallowwater habitats during the juvenile phase to the reef, once they mature. The present study found evidence that only a small number of the 942 species of fish observed on nearby coral reefs may utilise seagrass as such a corridor. Only 22 coral reef species utilised mangrove and only 15 utilised seagrass as nursery habitats. Although we found evidence that mangrove and seagrass may not directly support high coral reef fish diversity, it is important to realise that, of the juvenile fish that were recorded within the seagrass-mangrove continuum, some individual species are prominent apex predators and herbivores as adults on nearby coral reefs (e.g. Caranx ignoblis and Naso vlamingii) and are hence likely to be important in structuring reef communities (Mumby et al. 2007). Spawning in many fish families varies temporally (Victor 1986, Leis 1993). The present study, like many previous studies in the tropics, lacks year-round data and thus information on tempo- 
ral variation, therefore this study cannot fully dismiss the importance of the mangrove-seagrass continuum as a 'nursery' area for reef fish, but indicates a need for more year-round analysis.

The species found to utilise seagrass and mangrove as nursery habitats in the present study, although not hugely diverse, may also be of high ecomomic importance. Many of these are critically important to local fisheries (e.g. Siganidae, Lethrinidae, Lutjanidae, Caranx spp., Sphyraena spp.) (May 2005, Cullen 2007); hence, these habitats require consideration within resource management programs.

In conclusion, seagrass beds and non-estuarine mangroves in the Indo-Pacific support species-rich fish assemblages. Carnivorous fish were the most dominant feeding group found at high tide in the mangroves, whilst omnivores dominated on the mangrove edge and in seagrass. The number of herbivores was consistently low, although it is well documented that very few species of fish feed on mangrove or seagrass material directly (Cebrian \& Duarte 1998). Seagrass and mangrove were found to be important habitats for juveniles of some reef fish species. Juveniles of 22 coral reef species were found in mangrove and 15 in seagrass (Halford 2003). Although mangroves are not permanently inundated by tides in the Indo-Pacific, this study highlights their importance as fish habitats, supporting a greater abundance than seagrass beds during high tide. In the face of high rates of destruction and resource extraction, their role as an important fish habitat must be taken into consideration when developing effective resource management programs.

Acknowledgements. The authors thank all staff at Hoga Marine Research Centre that provided logistical support during data collection, in particular La Amat. This project benefited from funding from Caspian Services, Khazakstan (SG), Glasgow NHS (SG) and Operation Wallacea (RU).

\section{LITERATURE CITED}

Aguilar-Perera A, Appeldoorn RS (2007) Variation in juvenile fish density along the mangrove-seagrass-coral reef continuum in SW Puerto Rico. Mar Ecol Prog Ser 348:139-148

Alongi DM (2002) Present state and future of the world's mangrove forests. Environ Conserv 29:331-349

Baelde P (1990) Differences in the structures of fish assemblages in Thalassia testudinum beds in Guadeloupe, French West Indies, and their ecological significance. Mar Biol 105:163-173

Baldo F, Drake P (2002) A multivariate approach to the feeding habits of small fish in the Guadalquivir Estuary. J Fish Biol 61(Suppl. A):21-32

Blaber SJM, Brewer DT, Salini JP (1989) Species composition and biomasses of fishes in different habitats of a tropical northern Australian estuary: their occurrence in the adjoining seas and estuarine dependence. Estuar Coast Shelf Sci 29:509-531

Blaber SJM, Brewer DT, Salini JP (1995) Fish communities and the nursery role of the shallow inshore waters of a tropical bay in the gulf of Carpentaria, Australia. Mar Freshw Res 40:177-193

> Cebrian J, Duarte CM (1998) Patterns in leaf herbivory on seagrasses. Aquat Bot 60:67-82

Clarke KR, Warwick RM (1994) Changes in marine communities: an approach to statistical analysis and interpretation. Natural Environmental Research Council, Plymouth Marine Laboratory, Plymouth

Cullen LC (2007) Marine resource dependence, resource use patterns and identification of economic performance criteria within a small island community: Kaledupa, Indonesia. PhD Thesis, University of Essex, Colchester

> Dorenbosch M, Verweij MC, Nagelkerken I, Jiddawi N, van der Velde G (2004) Homing and daytime tidal movements of juvenile snappers (Lutjanidae) between shallow-water nursery habitats in Zanzibar, western Indian Ocean. Environ Biol Fishes 70:203-209

Dorenbosch M, Grol MGG, Christianen MJA, Nagelkerken I, van der Velde G (2005) Indo-Pacific seagrass beds and mangroves contribute to fish density and diversity on adjacent coral reefs. Mar Ecol Prog Ser 302:63-76

> Dorenbosch M, Verberk W, Nagelkerken I, van der Veldel G (2007) Influence of habitat configuration on connectivity between fish assemblages of Caribbean seagrass beds, mangroves and coral reefs. Mar Ecol Prog Ser 334: 103-116

Duke NC, Meynecke JO, Dittmann S, Ellison AM and others (2007) A world without mangroves? Science 317:41-42

Edgar GJ, Barrett NS, Morton AJ (2004) Biases associated with the use of underwater visual census techniques to quantify the density and size-structure of fish populations. J Exp Mar Biol Ecol 308:269-290

English S, Wilkinson C, Baker V (1997) Survey manual for tropical marine resources. Australian Institute of Marine Science, Townsville

Froese F, Pauly D (2008) Fishbase. Accessed 28th May 2008. www.fishbase.org

Halford A (2003) Fish diversity and distribution (Chapt 3). In: Pet-Soede L, Erdmann MV (eds) Rapid ecological assessment Wakatobi National Park. Directorate General of Forest Protection and Nature Conservation, Ministry of Forestry, Jakarta, WWF Indonesia Marine Program, Denpasar, Bali and The Nature Conservancy, Southeast Asia Center for Marine Protected Areas, Bali

Hemminga MA, Duarte CM (2000) Seagrass ecology. Cambridge University Press, Cambridge

Hutomo M, Peristiwady T (1996) Diversity, abundance and diet of fish in the seagrass beds of Lombok Island, Indonesia. In: Kuo J, Phillips RC, Walker DI, Kirkman H (eds) Seagrass biology: proceedings of an international workshop. Faculty of Science, University of Western Australia, Rottnest Island, p 205-212

> Jelbart JE, Ross PM, Connolly RM (2007) Fish assemblages in seagrass beds are influenced by the proximity of mangrove forests. Mar Biol 150:993-1002

> Khalaf M, Kochzius M (2002) Changes in trophic community structure of shore fishes at an industrial site in the Gulf of Aquaba, Red Sea. Mar Ecol Prog Ser 239:287-299

Laegdsgaard P, Johnson C (2001) Why do juvenile fish utilise mangrove habitats? J Exp Mar Biol Ecol 257:229-253

Laroche J, Baran E, Rasoanandrasana NB (1997) Temporal patterns in a fish assemblage of a semiarid mangrove zone in Madagascar. J Fish Biol 51:3-20

Leis JM (1993) Larval fish assemblages near Indo-Pacific coral reefs. Bull Mar Sci 54:206-227

> Lugendo BR, Pronker A, Cornelissen I, de Groene A and 
others (2005) Habitat utilization by juveniles of commercially important fish species in a marine embayment in Zanzibar, Tanzania. Aquat Living Resour 18:149-158

Lugendo BR, Nagelkerken I, van der Velde G (2006) The importance of mangroves, mud and sand flats, and seagrass beds as feeding areas for juvenile fishes in Chwaka Bay, Zanzibar: gut content and stable isotope analyses. J Fish Biol 69:1639-1661

Marguillier S, van der Velde G, Dehairs F, Hemminga MA, Rajagopal S (1997) Trophic relationships in an interlinked mangrove-seagrass ecosystem as traced by $\delta^{13} \mathrm{C}$ and $\delta^{15} \mathrm{~N}$. Mar Ecol Prog Ser 151:115-121

May D (2005) Folk taxonomy of reef fish and the value of participatory monitoring in Wakatobi National Park, southeast Sulawesi, Indonesia. SPC Trad Mar Res Manage Know Info Bull 18:18-35

Mumby PJ, Hastings A, Edwards HJ (2007) Thresholds and the resilience of Caribbean coral reefs. Nature 450:98-101

Nagelkerken I (2007) Are non-estuarine mangroves connected to coral reefs through fish migration? Bull Mar Sci 80:595-607

> Nagelkerken I, van der Velde G (2002) Do non-estuarine mangroves harbour higher densities of juvenile fish than adjacent shallow water and coral reef habitats in Curaçao (Netherlands Antilles)? Mar Ecol Prog Ser 245:191-204

Nagelkerken I, van der Velde G (2004) Relative importance of interlinked mangroves and seagrass beds as feeding habitats for juvenile reef fish on a Caribbean island. Mar Ecol Prog Ser 274:153-159

Nagelkerken I, Dorenbosch M, Verberk WCEP, Cocheret de la Moriniére E, van der Velde G (2000) Day-night shifts of fishes between shallow-water biotopes of a Caribbean bay, with emphasis on the nocturnal feeding of Haemulidae and Lutjanidae. Mar Ecol Prog Ser 194:55-64

Nagelkerken I, Kleijnen S, Klop T, van den Brand RACJ, Cocheret de la Morinière E, van der Velde G (2001) Dependance of Caribbean reef fishes on mangrove forests and seagrass beds as nursery habitats: a comparison of fish faunas between bays with and without mangrove forests/seagrass beds. Mar Ecol Prog Ser 214:225-235

> Nagelkerken I, Blaber SJM, Bouillon S, Green P and others (2008) The habitat function of mangroves for terrestrial and marine fauna: A review. Aquat Bot 89:155-185

Nakamura Y, Horinouchi M, Nakai T, Sano M (2003) Food habits of fishes in seagrass bed on a fringing coral reef at Iriomote Island, southern Japan. Ichthyol Res 50:15-22

Ogden JC, Zeimann JC (1977) Ecological aspects of coral reef-seagrass bed contacts in the Caribbean. Proc 3rd Int Coral Reef Symp 1:377-382

Orth RJ, Carruthers TJB, Dennison WC, Duarte CM and others (2006) A global crisis for seagrass ecosystems. Bioscience 56:987-996

Park JY, Kim IS, Lee YJ (2006) A study on the vascularization and structure of the epidermis of the air-breathing mudskipper, Periophthalmus magnuspinnatus (Gobiidae, Teleostei), along different parts of the body. J Appl Ichthyology 22:62-67

Parrish JD (1989) Fish communities of interacting shallowwater habitats in tropical oceanic regions. Mar Ecol Prog Ser 58:143-160

Quinn NJ, Kojis BL (1985) Does the presence of coral reef in proximity to a tropical estuary affect estuarine fish assemblage? Proc 5th Coral Reef Congress, Tahiti 5:445-450

Robertson AI, Blaber SJM (1992) Plankton, epibenthos and fish communities. In: Robertson AI, Alongi DM (eds) Tropical mangrove ecosystems. American Geophysical Union, Washington, DC, p 173-224

> Robertson AI, Duke NC (1987) Mangroves as nursery sitescomparisons of the abundance and species composition of fish and crustaceans in mangroves and other nearshore habitats in tropical Australia. Mar Biol 96:193-205

> Robertson AI, Duke NC (1990) Mangrove fish-communities in tropical Queensland, Australia: spatial and temporal patterns in densities, biomass and community structure. Mar Biol 104:369-379

Sasekumar A, Chong VC, Leh MU, D'Cruz RD (1992) Mangroves as a habitat for fish and prawns. Hydrobiologia 247:195-207

Sheaves M (2005) Nature and consequences of biological connectivity in mangrove systems. Mar Ecol Prog Ser 302: 293-305

Thollot P (1992) Importance of mangroves for Pacific reef fish species, myth or reality? Proc 7th Inter Coral Reef Symp, Guam 2:934-941

Unsworth RKF, Wylie E, Smith DJ, Bell JJ (2007a) Diel trophic structuring of seagrass bed fish assemblages in the Wakatobi Marine National Park, Indonesia. Estuar Coast Shelf Sci 72:81-88

Unsworth RKF, Bell JJ, Smith DJ (2007b) Tidal fish connectivity of reef and seagrass habitats in the Indo-Pacific. J Mar Biol Assoc UK 87:1287-1296

Unsworth RKF, Taylor JD, Powell A, Bell JJ, Smith DJ (2007c) The contribution of parrotfish (scarid) herbivory to ecosystem dynamics in the Indo-Pacific. Estuar Coast Shelf Sci 74:53-62

Unsworth RKF, Salinas De Leon P, Garrard S, Jompa J, Smith DJ, Bell JJ (2008) High connectivity of Indo-Pacific seagrass fish assemblages with mangrove and coral reef habitats. Mar Ecol Prog Ser 353:213-224

> Vance DJ, Haywood MDE, Heales DS, Kenyon RA, Loneragan NR (1996) How far do prawns and fish move into mangroves? Distribution of juvenile banana prawns Penaeus merguiensis and fish in a tropical mangrove forest in northern Australia. Mar Ecol Prog Ser 131:115-124

Verweij MC, Nagelkerken I, de Graaff D, Peeters M, Bakker EJ, van der Velde G (2006) Structure, food and shade attract juvenile coral reef fish to mangrove and seagrass habitats: a field experiment. Mar Ecol Prog Ser 306:257-268

> Victor BC (1986) Larval settlement and juvenile mortality in a recruitment-limited coral reef fish population. Ecol Monogr 56:145-160

Wilkinson CR (2008) Status of the Coral Reefs of the World: 2008. Global Coral Reef Monitoring Network and Reef and Rainforest Research Center, Townsville

Williams DM (1991) Patterns and processes in the distribution of coral reef fishes. In: Sale P (ed) The ecology of fishes on coral reefs. Academic Press, New York, p 437-474

Yáñez-Arancibia A, Lara-Domínguez AL, Day JW Jr (1993) Interactions between mangrove and seagrass habitats mediated by estuarine nekton assemblages: coupling of primary and secondary production. Hydrobiologia 264: $1-12$ 
Appendix 1. Table A1. Abundances of juveniles and adults (mean $\pm \mathrm{SE}$ ) of the fish species observed per $1000 \mathrm{~m}^{2}$ in each of the three habitats (mangrove, mangrove edge and seagrass) in the Kaledupa sub-region of the Wakatobi Marine National Park, SE Sulawesi, Indonesia. Fish were sampled in each of the habitats using underwater visual census at high tide. Adults and juveniles of all species were categorised by their usage of mangrove and seagrass habitats. h: herbivore; i: exclusive invertebrate feeder; f: fish-and-invertebrate feeder; o: omnivore; p: planktivore

\begin{tabular}{|c|c|c|c|c|c|c|c|c|}
\hline \multirow[t]{2}{*}{ Taxon } & \multirow[b]{2}{*}{$\begin{array}{c}\text { Reef } \\
\text { species }\end{array}$} & \multirow[b]{2}{*}{$\begin{array}{l}\text { Trophic } \\
\text { group }\end{array}$} & \multicolumn{3}{|c|}{ Juveniles $\longrightarrow$} & \multirow{2}{*}{$\begin{array}{l}\text { Man- } \\
\text { grove }\end{array}$} & \multirow{2}{*}{$\begin{array}{l}\text { - Adults } \\
\text { Mangrove } \\
\text { edge }\end{array}$} & \multirow[b]{2}{*}{ Seagrass } \\
\hline & & & $\begin{array}{l}\text { Man- } \\
\text { grove }\end{array}$ & $\begin{array}{l}\text { Mangrove } \\
\text { edge }\end{array}$ & Seagrass & & & \\
\hline \multicolumn{9}{|l|}{ Seagrass adult and juvenile } \\
\hline Naso vlamingii (Valenciennes, 1835) & $\mathrm{Y}$ & $\mathrm{h}$ & 0 & $3 \pm 2.83$ & $1.5 \pm 0.83$ & 0 & $0.33 \pm 0.33$ & 0 \\
\hline Dischistodus chrysopoecilus (Schlegel \& Müller, 1839) & & $\mathrm{h}$ & 0 & 0 & $1.5 \pm 0.93$ & 0 & 0 & $1.83 \pm 1.18$ \\
\hline Cheilio inermis (Forsskål, 1775) & $\mathrm{Y}$ & $\mathrm{f}$ & 0 & $0.17 \pm 0.17$ & $0.33 \pm 0.23$ & 0 & $0.17 \pm 0.17$ & $0.17 \pm 0.17$ \\
\hline Gerres acinaces (Bleeker, 1854) & & i & 0 & $0.17 \pm 0.17$ & $0.33 \pm 0.33$ & 0 & $0.67 \pm 0.67$ & 0 \\
\hline Rhinecanthus aculeatus (Linnaeus, 1758) & $\mathrm{Y}$ & $\mathrm{f}$ & 0 & 0 & $0.33 \pm 0.33$ & 0 & 0 & 0 \\
\hline Cheilodipterus quinquelineatus (Cuvier, 1828) & $\mathrm{Y}$ & f & 0 & 0 & $0.17 \pm 0.17$ & 0 & 0 & $0.67 \pm 0.46$ \\
\hline Diodon liturosus (Shaw, 1804) & $\mathrm{Y}$ & i & 0 & 0 & $0.17 \pm 0.17$ & 0 & 0 & 0 \\
\hline Lethrinus obsoletus (Forsskål, 1775) & & o & 0 & 0 & $0.17 \pm 0.17$ & 0 & 0 & 0 \\
\hline \multicolumn{9}{|l|}{ Seagrass adult only } \\
\hline Apogon hoevenii (Bleeker, 1854) & $\mathrm{Y}$ & i & 0 & 0 & 0 & 0 & $0.5 \pm 0.5$ & $1 \pm 1$ \\
\hline Dischistodus perspicillatus (Cuvier, 1830) & $\mathrm{Y}$ & $\mathrm{h}$ & 0 & 0 & 0 & 0 & $0.17 \pm 0.17$ & $0.67 \pm 0.67$ \\
\hline Parapercis millipunctata (Günther, 1860) & & o & 0 & 0 & 0 & 0 & 0 & $0.5 \pm 0.5$ \\
\hline Amblygobious phalaena (Valenciennes, 1837) & & o & 0 & 0 & 0 & 0 & 0 & $0.33 \pm 0.23$ \\
\hline Arothron manilensis (de Procé, 1822) & & i & 0 & 0 & 0 & 0 & 0 & $0.33 \pm 0.23$ \\
\hline Corythoichthys haematopterus (Bleeker, 1851) & & i & 0 & 0 & 0 & 0 & 0 & $0.33 \pm 0.33$ \\
\hline Leptoscarus vaigiensis (Quoy \& Gaimard, 1824) & $\mathrm{Y}$ & $\mathrm{h}$ & 0 & 0 & 0 & 0 & 0 & $0.33 \pm 0.33$ \\
\hline Balistapus undulatus (Park, 1797) & $\mathrm{Y}$ & $\mathrm{f}$ & 0 & 0 & 0 & 0 & 0 & $0.17 \pm 0.17$ \\
\hline Chrysiptera parasema (Fowler, 1918) & $\mathrm{Y}$ & i & 0 & 0 & 0 & 0 & 0 & $0.17 \pm 0.17$ \\
\hline Dascyllus aruanus (Linnaeus, 1758) & $\mathrm{Y}$ & o & 0 & 0 & 0 & 0 & 0 & $0.17 \pm 0.17$ \\
\hline Halichoeres margaritaceus (Valenciennes, 1839) & $\mathrm{Y}$ & $\mathrm{f}$ & 0 & 0 & 0 & 0 & 0 & $0.17 \pm 0.17$ \\
\hline Pardachirus pavoninus (Lacepède, 1802) & & i & 0 & 0 & 0 & 0 & 0 & $0.17 \pm 0.17$ \\
\hline Pomacentrus lepidogenys (Fowler \& Bean, 1928) & $\mathrm{Y}$ & i & 0 & 0 & 0 & 0 & 0 & $0.17 \pm 0.17$ \\
\hline Pseudomonacanthus macrurus (Bleeker, 1857) & $\mathrm{Y}$ & o & 0 & 0 & 0 & 0 & 0 & $0.17 \pm 0.17$ \\
\hline Syngnathoides biaculeatus (Bloch, 1785) & $\mathrm{Y}$ & i & 0 & 0 & 0 & 0 & $0.67 \pm 0.39$ & $0.17 \pm 0.17$ \\
\hline \multicolumn{9}{|l|}{ Mangrove juvenile only } \\
\hline Labridae sp.2 & & f & 0 & $1.67 \pm 1.67$ & 0 & 0 & 0 & 0 \\
\hline Labridae sp. 3 & & $\mathrm{f}$ & 0 & $0.67 \pm 0.67$ & 0 & 0 & 0 & 0 \\
\hline Siganus punctatus (Schneider \& Forster, 1801) & $\mathrm{Y}$ & $\mathrm{h}$ & 0 & $0.67 \pm 0.67$ & 0 & 0 & 0 & 0 \\
\hline Carangoides oblongus (Cuvier, 1833) & & f & 0 & $0.33 \pm 0.33$ & 0 & 0 & 0 & 0 \\
\hline Scolopsis bilineatus (Bloch, 1793) & $\mathrm{Y}$ & $\mathrm{f}$ & 0 & $0.17 \pm 0.17$ & 0 & 0 & 0 & 0 \\
\hline \multicolumn{9}{|l|}{ Mangrove adult and juvenile } \\
\hline Atherinomorus lacunosus (Forster, 1801) & & $\mathrm{p}$ & $556 \pm 481$ & $33.3 \pm 33.3$ & 0 & $2261 \pm 973$ & $83.3 \pm 52.1$ & 0 \\
\hline Hyporhamphus dussumieri (Valenciennes, 1847) & & $\mathrm{f}$ & $108 \pm 63.9$ & 0 & 0 & $12.2 \pm 9.61$ & 0 & 0 \\
\hline Neomyxus leuciscus (Günther, 1872) & & o & $70.6 \pm 48.2$ & 0 & 0 & $70.6 \pm 28.2$ & $5.17 \pm 5.17$ & 0 \\
\hline Apogon ceramensis (Bleeker, 1852) & & i & $33.3 \pm 28.9$ & 0 & 0 & $83.3 \pm 52.5$ & $1.67 \pm 1.67$ & 0 \\
\hline Siganus guttatus (Bloch, 1787) & $\mathrm{Y}$ & o & $10.6 \pm 4.97$ & $2.17 \pm 1.32$ & 0 & $2.22 \pm 1.92$ & $1.5 \pm 1.17$ & 0 \\
\hline Scolopsis temporalis & $\mathrm{Y}$ & $\mathrm{i}$ & $2.22 \pm 1.49$ & 0 & 0 & $6.67 \pm 4.2$ & $0.33 \pm 0.33$ & 0 \\
\hline Lutjanus ehrenbergii & $\mathrm{Y}$ & f & $1.67 \pm 0.78$ & $0.17 \pm 0.17$ & 0 & $16.7 \pm 3.7$ & $7.5 \pm 2.85$ & 0 \\
\hline Sphyraena barracuda (Edwards, 1771) & $\mathrm{Y}$ & $\mathrm{f}$ & $1.67 \pm 1.44$ & $0.5 \pm 0.28$ & 0 & $2.22 \pm 0.87$ & 0 & 0 \\
\hline Dischistodus pseudochrysopoecilus (Allen \& Robertson, 1974) & $\mathrm{Y}$ & $\mathrm{h}$ & $1.11 \pm 0.96$ & 0 & 0 & $2.22 \pm 1.92$ & 0 & 0 \\
\hline Caranx ignobilis (Forsskål, 1775) & $\mathrm{Y}$ & $\mathrm{f}$ & $1.11 \pm 0.96$ & $0.83 \pm 0.83$ & 0 & 0 & 0 & 0 \\
\hline Lutjanus russelli (Bleeker, 1849) & $\mathrm{Y}$ & f & $1.11 \pm 0.96$ & 0 & 0 & 0 & 0 & 0 \\
\hline Terapon jarbua (Forsskål, 1775) & & $\mathrm{f}$ & $0.56 \pm 0.48$ & $0.17 \pm 0.17$ & 0 & $6.11 \pm 4.81$ & $0.5 \pm 0.5$ & 0 \\
\hline Acanthurus nigrofuscus & $\mathrm{Y}$ & $\mathrm{h}$ & $0.56 \pm 0.48$ & 0 & 0 & $1.11 \pm 0.96$ & $0.67 \pm 0.67$ & 0 \\
\hline Plectorhinchus lessonii (Cuvier, 1830) & & $\mathrm{f}$ & $0.56 \pm 0.48$ & 0 & 0 & $1.11 \pm 0.66$ & 0 & 0 \\
\hline Acanthurus fowleri (de Beaufort, 1951) & & $\mathrm{h}$ & $0.56 \pm 0.48$ & 0 & 0 & 0 & 0 & 0 \\
\hline Arothron stellatus (Bloch \& Schneider, 1801) & $\mathrm{Y}$ & $\mathrm{i}$ & $0.56 \pm 0.48$ & 0 & 0 & 0 & 0 & 0 \\
\hline Toxotes jaculatrix (Pallas, 1767) & & o & $0.56 \pm 0.48$ & 0 & 0 & 0 & 0 & 0 \\
\hline Pomacentrus taeniometopon (Bleeker, 1852) & & $\mathrm{h}$ & 0 & $0.33 \pm 0.33$ & 0 & $6.11 \pm 5.29$ & 0 & 0 \\
\hline
\end{tabular}


Appendix 1 (continued)

\begin{tabular}{|c|c|c|c|c|c|c|c|c|}
\hline \multirow[t]{2}{*}{ Taxon } & \multirow[b]{2}{*}{$\begin{array}{c}\text { Reef } \\
\text { species }\end{array}$} & \multirow[b]{2}{*}{$\begin{array}{l}\text { Trophic } \\
\text { group }\end{array}$} & \multicolumn{3}{|c|}{ Juveniles - } & \multicolumn{2}{|c|}{ Adults } & \multirow[b]{2}{*}{ Seagrass } \\
\hline & & & $\begin{array}{l}\text { Man- } \\
\text { grove }\end{array}$ & $\begin{array}{l}\text { Mangrove } \\
\text { edge }\end{array}$ & Seagrass & $\begin{array}{l}\text { Man- } \\
\text { grove }\end{array}$ & $\begin{array}{c}\text { Mangrove } \\
\text { edge }\end{array}$ & \\
\hline \multicolumn{9}{|l|}{ Mangrove adult } \\
\hline Sphaeramia orbicularis & $\mathrm{Y}$ & f & 0 & 0 & 0 & $956 \pm 415$ & 0 & 0 \\
\hline Abudefduf septemfasciatus (Cuvier, 1830) & & o & 0 & 0 & 0 & $4.44 \pm 2.55$ & 0 & 0 \\
\hline Dischistodus fasciatus (Cuvier, 1830) & & $\mathrm{h}$ & 0 & 0 & 0 & $4.44 \pm 2.13$ & $10.3 \pm 3.27$ & 0 \\
\hline Hemiglyphidodon plagiometopon (Bleeker, 1852) & $\mathrm{Y}$ & $\mathrm{h}$ & 0 & 0 & 0 & $3.33 \pm 2.1$ & $0.83 \pm 0.59$ & 0 \\
\hline Pentapodus caninus (Cuvier, 1830) & Y & f & 0 & 0 & 0 & $1.67 \pm 1.05$ & $0.5 \pm 0.5$ & 0 \\
\hline Lutjanus decussatus (Cuvier, 1828) & $\mathrm{Y}$ & $\mathrm{f}$ & 0 & 0 & 0 & $1.11 \pm 0.66$ & $0.17 \pm 0.17$ & 0 \\
\hline Chaetodon lunula (Lacepède, 1802) & $\mathrm{Y}$ & o & 0 & 0 & 0 & $0.56 \pm 0.48$ & 0 & 0 \\
\hline Siganus virgatus (Valenciennes, 1835) & $\mathrm{Y}$ & $\mathrm{h}$ & 0 & 0 & 0 & $0.56 \pm 0.48$ & 0 & 0 \\
\hline Acreichthys tomentosus (Linnaeus, 1758) & Y & o & 0 & 0 & 0 & 0 & $0.17 \pm 0.17$ & 0 \\
\hline Bleniidae sp. & & o & 0 & 0 & 0 & 0 & $0.17 \pm 0.17$ & 0 \\
\hline Blenniela paula & & o & 0 & 0 & 0 & 0 & 0 & 0 \\
\hline Ephinephelus ongus (Bloch, 1790) & $\mathrm{Y}$ & $\mathrm{f}$ & 0 & 0 & 0 & 0 & $0.17 \pm 0.17$ & 0 \\
\hline Exyrias bellisimus (Smith, 1959) & & i & 0 & 0 & 0 & 0 & 0 & 0 \\
\hline Lutjanus fulvus (Forster, 1801) & Y & f & 0 & 0 & 0 & 0 & $0.33 \pm 0.33$ & 0 \\
\hline Scarus globiceps (Valenciennes, 1840) & & $\mathrm{h}$ & 0 & 0 & 0 & 0 & $5.33 \pm 3.01$ & 0 \\
\hline Scolopsis lineatus (Quoy \& Gaimard, 1824) & $\mathrm{Y}$ & i & 0 & 0 & 0 & 0 & $3 \pm 2.29$ & 0 \\
\hline Upeneus sundaicus (Bleeker, 1855) & $\mathrm{Y}$ & $\mathrm{i}$ & 0 & 0 & 0 & 0 & $0.17 \pm 0.17$ & 0 \\
\hline \multicolumn{9}{|l|}{ Seagrass and mangrove juvenile } \\
\hline Liza vaigiensis (Quoy \& Gaimard, 1825) & & o & $11.1 \pm 6.6$ & $4.17 \pm 2.13$ & $0.83 \pm 0.59$ & 0 & $0.67 \pm 0.52$ & $0.5 \pm 0.5$ \\
\hline Parupeneus macronemua (Lacepède, 1801) & & $\mathrm{i}$ & $0.56 \pm 0.48$ & $0.17 \pm 0.17$ & $0.5 \pm 0.37$ & 0 & 0 & $0.17 \pm 0.17$ \\
\hline Parupeneus barberinus (Lacepède, 1801) & $\mathrm{Y}$ & $\mathrm{i}$ & $4.44 \pm 2.35$ & $1.83 \pm 0.72$ & $1.5 \pm 0.75$ & 0 & 0 & 0 \\
\hline Lethrinus ornatus (Valenciennes, 1830) & $\mathrm{Y}$ & $\mathrm{f}$ & $0.56 \pm 0.48$ & $0.17 \pm 0.17$ & $1.5 \pm 0.86$ & 0 & 0 & 0 \\
\hline Caranx melampygus (Cuvier, 1833) & Y & $\mathrm{f}$ & $0.56 \pm 0.48$ & $0.5 \pm 0.5$ & $0.5 \pm 0.5$ & 0 & 0 & 0 \\
\hline Holgymnosus doliatus (Lacepède, 1801) & $\mathrm{Y}$ & $\mathrm{f}$ & $4.44 \pm 2.73$ & $1 \pm 1$ & $0.33 \pm 0.23$ & 0 & 0 & 0 \\
\hline \multicolumn{9}{|l|}{ Seagrass and mangrove adult and juvenile } \\
\hline Siganus canaliculatus & $\mathrm{Y}$ & o & $1.11 \pm 0.96$ & $1.33 \pm 0.75$ & $0.17 \pm 0.17$ & $45 \pm 12.9$ & $26.2 \pm 8.62$ & $35 \pm 12.1$ \\
\hline Choerodon anchorago & $\mathrm{Y}$ & f & $21.7 \pm 7.42$ & $11.3 \pm 4.65$ & $1 \pm 0.55$ & $29.4 \pm 11.3$ & $13.2 \pm 3.23$ & $2.33 \pm 1.02$ \\
\hline Acanthurus grammoptilus (Richardson, 1843) & & $\mathrm{h}$ & $5 \pm 2.13$ & $0.83 \pm 0.42$ & $0.5 \pm 0.5$ & $13.9 \pm 4.03$ & $11.7 \pm 3.22$ & $0.17 \pm 0.17$ \\
\hline Scolopsis ghanam & & $\mathrm{f}$ & $3.33 \pm 0.99$ & $1.33 \pm 0.71$ & $0.17 \pm 0.17$ & $12.2 \pm 3.33$ & $1.17 \pm 0.56$ & 0 \\
\hline Lethrinus harak (Forsskål, 1775) & $\mathrm{Y}$ & $\mathrm{f}$ & $22.2 \pm 6.13$ & $10.3 \pm 2.58$ & $11.7 \pm 2.71$ & $11.7 \pm 4.04$ & $1.83 \pm 1.05$ & $0.83 \pm 0.34$ \\
\hline Siganus fuscescens (Houttuyn, 1782) & $\mathrm{Y}$ & o & $3.89 \pm 2.34$ & $2 \pm 0.93$ & $0.5 \pm 0.37$ & $6.11 \pm 2.72$ & $2.67 \pm 1.48$ & $32 \pm 14.9$ \\
\hline Halichoeres trimaculatus (Quoy \& Gaimard, 1834) & $\mathrm{Y}$ & $\mathrm{f}$ & $0.56 \pm 0.48$ & 0 & $0.17 \pm 0.17$ & $5.56 \pm 3.37$ & $0.33 \pm 0.23$ & 0 \\
\hline Gerres oyena (Forsskål, 1775) & & o & $1.11 \pm 0.66$ & $14.8 \pm 6.24$ & $2.17 \pm 0.93$ & $1.67 \pm 0.78$ & $3.17 \pm 0.83$ & $4.83 \pm 1.93$ \\
\hline Lethrinus erythropterus (Valenciennes, 1830) & $\mathrm{Y}$ & f & $3.33 \pm 1.71$ & $0.67 \pm 0.67$ & $0.33 \pm 0.23$ & $0.56 \pm 0.48$ & $0.17 \pm 0.17$ & 0 \\
\hline \multicolumn{9}{|l|}{ Seagrass and mangrove adult, juvenile mangrove } \\
\hline Scolopsis trilineatus & $\mathrm{Y}$ & i & 0 & $0.17 \pm 0.17$ & 0 & $40.6 \pm 11.4$ & $25.3 \pm 4.69$ & $7 \pm 3.49$ \\
\hline \multicolumn{9}{|l|}{ Seagrass and mangrove adult, juvenile seagrass } \\
\hline Halichoeres argus (Bloch \& Schneider, 1801) & & f & 0 & 0 & $1.17 \pm 0.74$ & $4.44 \pm 2.99$ & $1 \pm 0.84$ & $8.83 \pm 3.96$ \\
\hline Halichoeres scapularis (Bennett, 1832) & & $\mathrm{i}$ & 0 & 0 & $0.67 \pm 0.52$ & $1.67 \pm 1.05$ & $2 \pm 1.2$ & $0.5 \pm 0.5$ \\
\hline Halichoeres papilionaceus (Valenciennes, 1839) & & $\mathrm{i}$ & 0 & 0 & $0.5 \pm 0.5$ & $1.11 \pm 0.66$ & 0 & $2.83 \pm 1.26$ \\
\hline \multicolumn{9}{|l|}{ Seagrass and mangrove adult } \\
\hline Gobiidae sp. & & o & 0 & 0 & 0 & $5 \pm 1.44$ & $4.33 \pm 1.15$ & $2.33 \pm 0.99$ \\
\hline Lethrinus variegatus (Valenciennes, 1830) & Y & i & 0 & 0 & 0 & $0.56 \pm 0.48$ & $0.33 \pm 0.23$ & $1.5 \pm 0.58$ \\
\hline Apogon hartzfeldii (Bleeker, 1852) & Y & & 0 & 0 & 0 & $22.2 \pm 19.2$ & 0 & $0.33 \pm 0.33$ \\
\hline Amblygobius sphynx (Valenciennes, 1837) & & $\mathrm{i}$ & 0 & 0 & 0 & $2.78 \pm 1.69$ & $0.5 \pm 0.37$ & $0.33 \pm 0.23$ \\
\hline Labridae sp.1 & & $\mathrm{i}$ & 0 & 0 & 0 & $0.56 \pm 0.48$ & 0 & $0.17 \pm 0.17$ \\
\hline Myrichthys colubrinus (Boddaert, 1781) & & $\mathrm{f}$ & 0 & 0 & 0 & $0.56 \pm 0.48$ & 0 & $0.17 \pm 0.17$ \\
\hline Taeniura lymma (Forsskål, 1775) & & $\mathrm{f}$ & 0 & 0 & 0 & $0.56 \pm 0.48$ & 0 & $0.17 \pm 0.17$ \\
\hline Total & & & $874 \pm 475$ & $95 \pm 40.5$ & $28.7 \pm 3.98$ & $3649 \pm 983$ & $219 \pm 55.4$ & $108 \pm 24.4$ \\
\hline
\end{tabular}

Editorial responsibility: Hans Heinrich Janssen, Oldendorf/Luhe, Germany
Submitted: June 16, 2008; Accepted: January 8, 2009 Proofs received from author(s): February 17, 2009 